\title{
Effect of Selected Plant Growth Regulators on Yield and Stem Height of Spring Wheat in Ontario
}

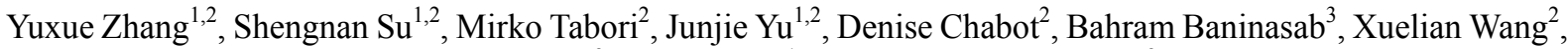 \\ Bao-Luo $\mathrm{Ma}^{2}$, Chunyan $\mathrm{Li}^{1} \&$ Shahrokh Khanizadeh ${ }^{2}$ \\ ${ }^{1}$ Key Laboratory of Crop Genetics and Physiology of Jiangsu Province/Co-Innovation Center for Modern \\ Production Technology of Grain Crops, Yangzhou University, Yangzhou, China \\ ${ }^{2}$ Ottawa Research and Development Centre, Agriculture and Agri-Food Canada, Ottawa, Ontario, Canada \\ ${ }^{3}$ Department of Horticulture, College of Agriculture, Isfahan University of Technology, Isfahan, Iran \\ Correspondence: Shahrokh Khanizadeh, Ottawa Research and Development Centre, Agriculture and Agri-Food \\ Canada, K. W. Neatby Building, 960 Carling Ave, Ottawa, Ontario, K1A 0C6, Canada. E-mail: \\ shahrokh.khanizadeh@agr.gc.ca \\ Chunyan Li, Key Laboratory of Crop Genetics and Physiology of Jiangsu Province/Co-Innovation Center for \\ Modern Production Technology of Grain Crops, Yangzhou University, Yangzhou, 225009, China. E-mail: \\ licy@yzu.edu.cn
}

Received: July 5, 2017

doi:10.5539/jas.v9n12p30
Accepted: September 12, $2017 \quad$ Online Published: November 15, 2017

URL: https://doi.org/10.5539/jas.v9n12p30

The research is financially supported, in part by China Scholarship Council.

\begin{abstract}
Lodging is an important limiting factor in wheat because it affects growth, yield and grain quality. Plant growth regulators (PGRs) are often used to restrain elongation of internodes, improve lodging traits, and protect yield potentials. An experiment was set up in the greenhouse at the Ottawa Research and Development Centre (ORDC) to study the effect of the selected PGRs (Manipulator, the active ingredient of which is chlormequat; and Palisade, the active ingredient of which is trinexapac-ethyl) on yield, stem height and morphological traits in six spring wheat cultivars (AC Carberry, AAC Scotia, Hoffman, Fuzion, FL62R1, and AW725). Both PGRs reduced plant height and caused a $6 \%$ to $48 \%$ reduction in the length of the second basal internode. The mixture of the two PGRs had a synergistic affect and made the stem shorter. The application of PGRs significantly reduced lodging, increased stem diameter, thickness, filling degree, and stem strength, and increased leaf relative chlorophyll content. However, application of PGRs significantly reduced grain yield, and the combination of the two PGRs (Manipulator and Palisade) had a synergistic effect and lowered the yield. In general, the effect of Palisade was more evident than that of Manipulator.
\end{abstract}

Keywords: plant height, lodging, Manipulator, microstructure, Palisade, plant growth regulators, spring wheat, yield

\section{Introduction}

Wheat is the leading cereal consumed in the world (Oleson, 1994). The UN predicts that the world population will grow over the next decades. For this reason, the world needs to increase crop yields through better use of water and fertilizer in order to guarantee food security and environmental protection (Foulkes et al., 2011). Wheat lodging reduces harvestability and quality by disrupting the supply and intake of water to the developing kernels. Lodging-induced reduction of grain yield is reported to range from $7 \%$ to $61 \%$ (Ref). A good way to improve yield potential is to optimize dry matter partitioning to the developing spike and grain in order to increase spike fertility and harvest index while maintain lodging resistance (Foulkes et al., 2011). At the same time, improving lodging resistance is an essential strategy for increasing the yield. This can be done via either breeding and selection or the use of PGRs.

Stem lodging results from bending of the basal stem internodes (Baker et al., 1998; Pinthus, 1973). It is defined as the permanent displacement of cereal stems from the vertical position due to internal and external factors and 
is a common problem in wheat. Stem lodging can be caused by the weight accumulated in heads, wind and basal internode. Other factors that account for lodging include an abundant supply of nutrients, a high seed rate, and inappropriate irrigation methods (Berry et al., 2004, 2006; Pinthus, 1973).

The common view is to consider the height of the plant as the main target for preventing lodging (Wiersma et al., 2011). Many breeders therefore focused on selecting dwarfing genes to reduce lodging susceptibility and increase potential yields through chemical and agronomic practices. The semi-dwarf cultivars have a larger stem diameter and wall width that greatly resolved the problem of lodging. However, in some cases, grain yield could also be decreased if the height is shortened too much (Guoping et al., 2001). The relationship between high yields and lodging resistance depends not only on plant height, but also on stem structure, photosynthetic capacities and vascular bundles (Feng et al., 2014). The basal internodes play an important role in lodging resistance. Cultivation methods need to be improved in order to reduce lodging and increase grain yields further.

The reductions of plant height were associated with reducing elongation of the internodes. PGRs are often used as an insurance measure to reduce the incidence of lodging by mimicking or changing the production of hormones, which play an important role in improving stem structure and increasing yields (Berry \& Spink, 2012; Pinthus, 1973). Trinexapac-ethyl simulates the cosubstrate of dioxygenases that compete for the biding site to inhibit the formation of gibberellin while chlormequat restricts enzymes that involved in gibberellin biosynthesis (Rademacher, 2000). Chlormequat involves the earlier step and Trinexapac-ethyl inhibits the last stage of gibberellin metabolism (Srivastava, 2002). Previous studies have reported that the use of PGRs can restrain internode elongation (Guoping et al., 2001). Piñera-Chavez et al. (2016) found a positive correlation between stem strength and diameter and wall width. Spraying PGRs at the right growth stage can improve stem quality, prevent lodging, and increase crop yields (Cailong et al., 2017). The typical changes caused by the application of trinexapac-ethyl are a reduction in plant height, an increase in wheat stem diameter and strength, and a darker green color in leaves (Tolbert, 1960; Zagonel \& Fernandes, 2007). Shekoofa and Emam (2008) reported that the use of PGRs can increase wheat yields, but Zagonel and Fernandes (2007) found that in some instances, the use of PGRs does not affect yields substantially. The application of chlormequat and paclobutrazol can shorten the stem length and increase grain yields, while gibberellin has the opposite effect (Rajala \& Peltonen-Sainio, 2001; Pinthus \& Rudich, 1967; Wiersma et al., 1986). However, Espindula et al. (2009) found that trinexapac-ethyl at high rates reduced grain yields.

Most lodging studies have investigated whether wheat height, center of gravity height, stem strength and length, diameter, and wall thickness (Kelbert et al., 2004; Tripathi et al., 2003) were the dominant parameters affecting lodging. There are few reports about the underlying mechanism of lodging-related traits. We focus on two PGRs-Manipulator, the active ingredient of which is chlormequat, and Palisade, the active ingredient of which is trinexapac-ethyl - to evaluate the individual and combined effects of these PGRs on selected Canadian hard red spring wheat cultivars in terms of yield, stem structure, relative chlorophyll content, lodging, height, and stem cell length, width and numbers, which may be influenced by PGRs. The main objective of this study was to compare the effect of different combinations of PGRs at the beginning of the jointing stage (Zadoks growth stage 31 ) in order to provide a theoretical basis of optimal combinations to prevent lodging and increase the grain yield in spring wheat.

\section{Materials and Methods}

\subsection{Plant Material and Experimental Conditions}

The experiment was carried out in Ottawa, Canada. Six Canadian spring wheat cultivars (AC Carberry, AAC Scotia, Hoffman, Fuzion, FL62R1, AW725) were chosen for this experiment, they are all high yielding, and tall plants of AAC Scotia and AW725. Wheat was planted in a greenhouse at Agriculture and Agri-Food Canada's Ottawa Research and Development Centre. The temperatures in the greenhouse were $23{ }^{\circ} \mathrm{C}$ during the day and $18{ }^{\circ} \mathrm{C}$ at night, and the day and night lengths were $16 / 8$ hours. Wheat was sown by hand at a depth of $2 \mathrm{~cm}$ on November 7, 2016. Pots were filled with a mixture of sand and loam soil. Eight seeds were sown per pot, and four seedlings were kept after one month. PGRs (Manipulator, Palisade, combination of Manipulator and Palisade) were applied at the jointing stage (Zadoks growth stage 31). The PGRs were applied in the following concentrations which were recommended by manufacturer: $1.8 \mathrm{~L} /$ ha for Manipulator; $0.88 \mathrm{~L} /$ ha for Palisade; 1 $\mathrm{L} / \mathrm{ha}$ for Manipulator and $0.42 \mathrm{~L} / \mathrm{ha}$ for Palisade in combination (Palisade EC Syngenta, 2015; Manipulator 620, 2015). The trial used a completely randomized design with four replications for each treatment. Another four replications that received no PGRs served as the control, which were sprayed with water. 


\subsection{Measurements of Stem Morphology Traits}

The length, diameter, dry weight, and breaking resistance of the second basal internode and the center of gravity height and fresh weight of eight main shoots were measured 20 days after the anthesis stage. The diameters of second basal internodes were measured using a digital caliper accurate to $0.01 \mathrm{~mm}$. The fresh weight of the shoot included the head, leaf and sheath. The center of gravity height is the length from the base to the balance fulcrum. Stem breaking resistance was determined by the three-point bending test using a MultiTest 2.5-i stand (Mecmesin, Slinfold, UK). Breaking resistance was measured in the center of the second basal internode, which was aligned horizontally with the middle point between the two fulcra with a length (L) of $5 \mathrm{~cm}$. The breaking value, displayed in $\mathrm{N}$, was recorded. The filling degree was calculated by dividing the dry weight of the second basal internode by the length of the second internode. The culm lodging resistance index (CLRI) was calculated using the following equation:

$$
\text { Culm lodging resistance index }=\frac{\text { Breaking resistance strength of second basal internode }}{\text { Center of gravity height } \times \text { Fresh weight of shoot }}
$$

There were four replications for each treatment.

\subsection{Analysis of Anatomical Features}

\subsubsection{Confocal Laser Scanning Microscopy (CLSM)}

At about 20 days after the anthesis stage, a cross-section of the second basal internode was cut from the middle of the internode with binoculars, forceps and a fine razor blade. Sections were stained in calcofluor white $(0.08 \%$ in PBS) for $10 \mathrm{~min}$ and rinsed in water twice for $5 \mathrm{~min}$. Next, sections were mounted in Fluoromount-G and observed with a confocal LSM 800 (Carl Zeiss MicroImaging, Göttingen, Germany) equipped with an EC Plan-NeoFluar 5x/0.16 M27 objective lens. The cellulose, lignin and chlorophyll were visualized using excitation wavelengths of 405, 488 and $633 \mathrm{~nm}$ and emission bands of 410 to $515 \mathrm{~nm}$ (blue), 515 to $645 \mathrm{~nm}$ (green) and 645 to $700 \mathrm{~nm}$ (red) respectively.

The Tiles module of the Zen 2 software was used to produce images of the entire sample. The thickness of the stem wall (parenchyma and sclerenchyma were included), the width of the outer radius, and the area of parenchyma and sclerenchyma were measured. The measurements and the transfer of data to Excel spreadsheets were performed using the same software.

\subsubsection{Brightfield Microscopy}

A sample of the second basal internode was cut from the middle of the internode by hand using a fine razor blade in a longitudinal manner in order to include the epidermis. Sections were fixed in glutaraldehyde $3 \%$ in $0.1 \mathrm{M}$ phosphate buffer at $\mathrm{pH} 7.2$ and stored at $4{ }^{\circ} \mathrm{C}$ until they were ready for microscopy. Sections were rinsed in water, mounted in glycerol, and observed using a Zeiss Z1 Axio Observer inverted bright-field microscope (Carl Zeiss MicroImaging, Göttingen, Germany) with a Fluar 10x/0.50 M27 objective lens and an AxioCam HR R3 digital camera.

The length and width of cells and the numbers of cells per $900 \mu \mathrm{m}$ were measured. The measurements and the transfer of data to Excel spreadsheets were performed using Zen 2 Lite software from Zeiss.

\subsection{Analysis of Agronomic Traits}

Agronomic traits measured for this study included relative chlorophyll content, plant height and grain yield (g/pot). The height of the main shoot was measured at seven-day intervals after PGR spraying until the height was fixed. Plant height was measured from the base of the shoot to the tip of the ears, excluding awns. The relative chlorophyll content was recorded at 10-day intervals four times from 10 days after PGR spraying using a SPAD-502 chlorophyll meter (Konica Minolta Sensing Inc., Osaka, Japan).

\subsection{Statistical Analyses}

Variables were subjected to one-way analysis of variance (ANOVA), using the GLM procedure of the SAS software package (SAS Institute, 1989). Treatment means were compared using the least significant difference (LSD) test at the $\mathrm{P}=0.05$ level when the effect was significant.

\section{Results}

\subsection{Plant Height and Yield}

The most important effect of the PGRs was a reduction in plant height. In this experiment, the height was measured at seven-day intervals. No lodging occurred in any treatment. Analysis of plant height at different times showed consistent differences between treatments across all six cultivars (Table 1). The differences 
suggested that PGRs were extremely effective at reducing plant heights. Compared with the control, the plant height was reduced significantly by the application of the PGRs. The combination of Manipulator and Palisade produced the shortest plant height, with the rate of reduction ranging from $22 \%$ to $48 \%$ in different cultivars. Palisade produced medium heights, and Manipulator reduced plant height the least, with the rate of reduction ranging from $6 \%$ to $33 \%$ in different cultivars.

PGRs had significant effects on grain yield (Table 1). Because the wheat was planted in a greenhouse, no lodging occurred, so the control produced the maximum yield, followed by the application of the combination of Manipulator and Palisade. Compared with the control, the yield was highest after spraying the combinated PGRs, which reduced the yield by $33.6 \%, 5.6 \%, 16.3 \%, 17.0 \%, 6.9 \%$, and $17.8 \%$ in AC Carberry, AAC Scotia, Hoffman, Fuzion, FL62R1, and AW725 respectively, whereas the yield after spraying Palisade strongly decreased by $45.5 \%, 41.3 \%, 22.9 \%, 37.5 \%, 14.5 \%$, and $30.9 \%$ in these cultivars, respectively. The results showed that the use of Manipulator and Palisade individually and in combination was effective at reducing height and yield loss. The effect was more evident with Palisade than with Manipulator.

\subsection{Microstructure of Basal Internode}

Increasing the proportion of sclerenchyma and parenchyma reinforces lodging resistance. It was clear that the proportion of sclerenchyma tissue was significantly increased by PGRs among all cultivars (Table 1; Figure 1). The mixture of the two PGRs led to the biggest proportion, which could enhance lodging resistance in most cultivars. The application of Manipulator yielded the smallest proportion, but this was still higher than in the control. The variance of the proportion of parenchyma was similar to what was seen with sclerenchyma (Table 1; Figure 1), but in comparison with the control, the cultivars differed in terms of which PGR-Manipulator or Palisade-resulted in less-increased proportions. 
Table 1. Effect of PGRs on plant height at seven-day intervals, and on yield and microstructure of second basal internode at physiology maturity

\begin{tabular}{|c|c|c|c|c|c|c|c|c|}
\hline Cultivar & Treatment & $\begin{array}{l}\text { 34-Day } \\
\text { Height }(\mathrm{cm})\end{array}$ & $\begin{array}{l}\text { 41-Day } \\
\text { Height }(\mathrm{cm})\end{array}$ & $\begin{array}{l}\text { 48-Day } \\
\text { Height (cm) }\end{array}$ & $\begin{array}{l}\text { 55-Day } \\
\text { Height }(\mathrm{cm})\end{array}$ & $\begin{array}{l}\text { Yield } \\
\text { (g/pot) }\end{array}$ & $\operatorname{PST}(\%)$ & PPT (\%) \\
\hline \multirow{5}{*}{ AC Carberry } & Control & 28.2 & 48.5 & 75.0 & 76.9 & 31.7 & 11.0 & 51.8 \\
\hline & Manipulator & 26.7 & 38.8 & 68.4 & 71.9 & 20.7 & 13.0 & 56.5 \\
\hline & Palisade & 25.7 & 38.2 & 59.7 & 66.8 & 17.3 & 14.7 & 55.4 \\
\hline & Manipulator + Palisade & 20.5 & 36.5 & 53.6 & 59.5 & 21.0 & 14.9 & 57.8 \\
\hline & $\operatorname{LSD}(\mathrm{P}=0.05)$ & 0.7 & 1.0 & 0.8 & 0.6 & 0.4 & 0.8 & 0.7 \\
\hline \multirow{5}{*}{ AAC Scotia } & Control & 26.7 & 45.9 & 71.3 & 93.5 & 33.2 & 10.4 & 49.9 \\
\hline & Manipulator & 23.2 & 34.0 & 51.1 & 85.4 & 26.5 & 10.7 & 66.0 \\
\hline & Palisade & 22.9 & 32.0 & 44.0 & 69.1 & 19.5 & 11.7 & 68.3 \\
\hline & Manipulator + Palisade & 21.8 & 28.3 & 39.3 & 58.0 & 31.3 & 14.6 & 81.9 \\
\hline & $\operatorname{LSD}(P=0.05)$ & 0.6 & 0.9 & 0.8 & 0.7 & 0.3 & 0.3 & 1.2 \\
\hline \multirow{5}{*}{ Hoffman } & Control & 25.1 & 58.9 & 77.0 & 115.6 & 34.1 & 11.3 & 76.9 \\
\hline & Manipulator & 24.7 & 41.3 & 61.3 & 81.8 & 27.9 & 11.7 & 85.1 \\
\hline & Palisade & 21.2 & 28.3 & 47.6 & 64.9 & 26.3 & 12.3 & 85.3 \\
\hline & Manipulator + Palisade & 20.5 & 28.0 & 45.0 & 62.4 & 28.6 & 13.0 & 85.6 \\
\hline & $\operatorname{LSD}(\mathrm{P}=0.05)$ & 0.6 & 1.0 & 0.7 & 0.5 & 0.2 & 0.2 & 1.0 \\
\hline \multirow{5}{*}{ Fuzion } & Control & 23.3 & 47.3 & 78.3 & 99.9 & 33.9 & 11.4 & 57.8 \\
\hline & Manipulator & 22.8 & 35.4 & 61.6 & 83.2 & 24.7 & 11.7 & 64.4 \\
\hline & Palisade & 20.1 & 29.1 & 41.9 & 65.2 & 21.2 & 12.3 & 64.5 \\
\hline & Manipulator + Palisade & 18.1 & 27.2 & 38.8 & 61.3 & 28.1 & 12.4 & 65.3 \\
\hline & $\operatorname{LSD}(\mathrm{P}=0.05)$ & 0.7 & 0.9 & 0.9 & 0.5 & 0.3 & 0.5 & 0.7 \\
\hline \multirow{5}{*}{ FL62R1 } & Control & 23.7 & 45.3 & 69.2 & 100.6 & 27.2 & 11.5 & 47.9 \\
\hline & Manipulator & 21.1 & 31.9 & 57.2 & 72.5 & 24.8 & 12.7 & 64.0 \\
\hline & Palisade & 18.2 & 26.2 & 44.4 & 55.9 & 23.3 & 13.1 & 63.1 \\
\hline & Manipulator + Palisade & 17.9 & 23.5 & 37.4 & 51.8 & 25.4 & 13.5 & 64.3 \\
\hline & $\operatorname{LSD}(\mathrm{P}=0.05)$ & 0.7 & 0.8 & 0.9 & 0.4 & 0.2 & 0.7 & 0.8 \\
\hline \multirow{5}{*}{ AW725 } & Control & 22.8 & 43.2 & 70.7 & 107.1 & 37.3 & 11.1 & 55.7 \\
\hline & Manipulator & 21.2 & 34.8 & 52.2 & 71.1 & 28.2 & 11.4 & 66.6 \\
\hline & Palisade & 19.1 & 25.0 & 36.9 & 65.6 & 25.8 & 13.1 & 66.9 \\
\hline & Manipulator + Palisade & 17.5 & 24.5 & 36.1 & 55.5 & 30.7 & 13.2 & 66.9 \\
\hline & $\operatorname{LSD}(P=0.05)$ & 0.7 & 0.7 & 0.9 & 0.6 & 0.1 & 0.9 & 1.1 \\
\hline
\end{tabular}

Note. PST: proportion of sclerenchyma tissue (\%); PPT: proportion of parenchyma tissue (\%); LSD (0.05): least significant difference at the 0.05 level. 

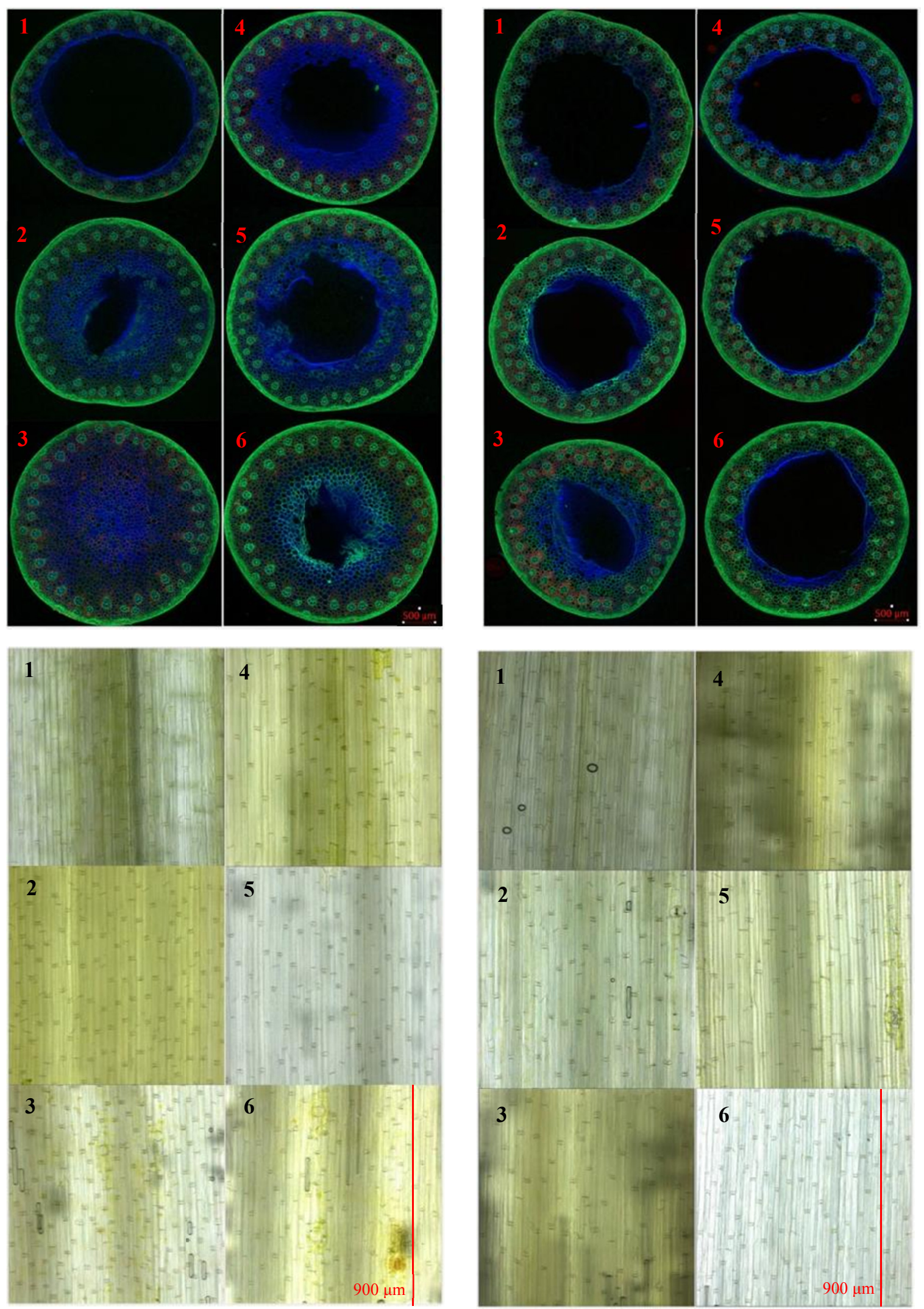

Manipulator \& Palisade

\section{Control}

Figure 1. Stem anatomy of selected spring wheat lines treated with Manipulator and Palisade vs. control Note. 1: AC Carberry; 2: AAC Scotia; 3: Hoffman; 4: Fuzion; 5: FL62R1; 6: AW725. 
In comparison with the control, the application of PGRs significantly reduced the length and increased the width and numbers per $900 \mu \mathrm{m}$ of the second basal internode cells (Table 2; Figure 1), and the combination of Manipulator and Palisade produced the smallest length and largest width and numbers. The PGRs reduced cell length by $37.6 \%$ to $52.3 \%$, while increased the width by $11.3 \%$ to $22.7 \%$, and the numbers by $35.4 \%$ to $88.5 \%$. The result was consistent with the effect of PGRs on length, diameter and wall thickness and filling degree between different cultivars.

Table 2. Effect of PGRs on length, width and numbers per $900 \mu \mathrm{m}$ of the second basal internode cells

\begin{tabular}{|c|c|c|c|c|}
\hline Cultivar & Treatment & Length $(\mu \mathrm{m})$ & Width $(\mu \mathrm{m})$ & Number (per $900 \mu \mathrm{m}$ ) \\
\hline \multirow{5}{*}{ AC Carberry } & Control & 343.3 & 20.3 & 2.6 \\
\hline & Manipulator & 255.9 & 21.5 & 3.2 \\
\hline & Palisade & 222.2 & 22.6 & 3.5 \\
\hline & Manipulator + Palisade & 213.9 & 24.9 & 3.6 \\
\hline & $\operatorname{LSD}(\mathrm{P}=0.05)$ & 4.7 & 0.5 & 0.1 \\
\hline \multirow{5}{*}{ AAC Scotia } & Control & 368.8 & 16.8 & 2.4 \\
\hline & Manipulator & 261.0 & 17.5 & 3.5 \\
\hline & Palisade & 200.5 & 18.6 & 4.4 \\
\hline & Manipulator + Palisade & 176.0 & 19.9 & 4.6 \\
\hline & $\operatorname{LSD}(\mathrm{P}=0.05)$ & 3.8 & 0.5 & 0.0 \\
\hline \multirow{5}{*}{ Hoffman } & Control & 349.3 & 20.8 & 3.3 \\
\hline & Manipulator & 210.3 & 21.7 & 4.3 \\
\hline & Palisade & 190.2 & 23.5 & 4.4 \\
\hline & Manipulator + Palisade & 177.2 & 24.4 & 4.8 \\
\hline & $\operatorname{LSD}(\mathrm{P}=0.05)$ & 5.4 & 0.6 & 0.0 \\
\hline \multirow{5}{*}{ Fuzion } & Control & 413.9 & 19.8 & 2.2 \\
\hline & Manipulator & 287.8 & 21.1 & 2.9 \\
\hline & Palisade & 255.0 & 23.1 & 3.1 \\
\hline & Manipulator + Palisade & 227.7 & 24.3 & 3.5 \\
\hline & $\operatorname{LSD}(P=0.05)$ & 11.2 & 0.4 & 0.4 \\
\hline \multirow{5}{*}{ FL62R1 } & Control & 378.9 & 20.6 & 2.5 \\
\hline & Manipulator & 252.6 & 21.2 & 2.9 \\
\hline & Palisade & 221.6 & 22.2 & 3.5 \\
\hline & Manipulator + Palisade & 190.2 & 24.2 & 3.7 \\
\hline & $\operatorname{LSD}(\mathrm{P}=0.05)$ & 8.7 & 0.5 & 0.4 \\
\hline \multirow{5}{*}{ AW725 } & Control & 355.3 & 23.3 & 2.5 \\
\hline & Manipulator & 274.6 & 24.1 & 3.4 \\
\hline & Palisade & 243.4 & 25.1 & 3.5 \\
\hline & Manipulator + Palisade & 221.8 & 25.9 & 3.7 \\
\hline & $\operatorname{LSD}(\mathrm{P}=0.05)$ & 6.4 & 0.5 & 0.0 \\
\hline
\end{tabular}

Note. LSD (0.05): least significant difference at the 0.05 level.

\subsection{Morphology and Lodging Traits of the Basal Internode}

Lodging resistance depends on stem diameter, stem wall thickness and stem strength. The features in Table 3 were the traits strongly related to lodging resistance. They showed consistent differences between different treatments across cultivars, and the differences were detected for most traits (Table 3, Figure 1). For the six cultivars, PGRs significantly reduced the length of the second basal internode and increased its diameter, thickness, strength, and filling degree. Compared with the control, those traits were reduced to their minimum or increased to their maximum after the application of the combination of Manipulator and Palisade. Stem strength was closely associated with lodging resistance, having increased by $93 \%, 66 \%, 60 \%, 52 \%, 39 \%$, and $105 \%$ in AC Carberry, AAC Scotia, Hoffman, Fuzion, FL62R1, and AW725 respectively. 
In comparison with the control, it was apparent that the CRLI was increased by the PGRs, and the application of the combination of Manipulator and Palisade produced the highest CRLI (Table 3), which means that the combined application of both PGRs exerted a synergistic effect on the formation of stem structure, and thus thus displayed better lodging resistance.

Table 3. Effect of PGRs on second basal internode lodging traits

\begin{tabular}{|c|c|c|c|c|c|c|c|}
\hline Cultivar & Treatment & $\begin{array}{l}\text { Length } \\
(\mathrm{cm})\end{array}$ & $\begin{array}{l}\text { Diameter } \\
(\mathrm{mm})\end{array}$ & $\begin{array}{l}\text { Thickness } \\
(\mathrm{mm})\end{array}$ & $\begin{array}{l}\text { Strength } \\
\text { (N) }\end{array}$ & $\begin{array}{l}\text { Filling Degree } \\
\left(\mathrm{mg} \mathrm{DW} \mathrm{cm}^{-1}\right)\end{array}$ & CRLI \\
\hline \multirow{5}{*}{ AC Carberry } & Control & 7.4 & 3.1 & 0.5 & 5.2 & 10.8 & 1.5 \\
\hline & Manipulator & 5.9 & 3.3 & 0.6 & 6.5 & 14.5 & 2.7 \\
\hline & Palisade & 5.5 & 3.4 & 0.7 & 5.8 & 14.9 & 2.9 \\
\hline & Manipulator + Palisade & 4.3 & 4.0 & 0.8 & 9.9 & 26.1 & 3.1 \\
\hline & $\operatorname{LSD}(\mathrm{P}=0.05)$ & 0.8 & 0.1 & 0.1 & 0.4 & 0.4 & 0.1 \\
\hline \multirow{5}{*}{ AAC Scotia } & Control & 9.9 & 3.2 & 0.6 & 9.3 & 16.7 & 1.5 \\
\hline & Manipulator & 6.4 & 3.3 & 0.7 & 10.8 & 26.2 & 1.8 \\
\hline & Palisade & 4.8 & 3.5 & 0.9 & 11.2 & 35.7 & 3.0 \\
\hline & Manipulator + Palisade & 4.5 & 3.8 & 1.7 & 15.4 & 48.9 & 3.5 \\
\hline & $\operatorname{LSD}(\mathrm{P}=0.05)$ & 0.6 & 0.1 & 0.4 & 0.6 & 0.2 & 0.1 \\
\hline \multirow{5}{*}{ Hoffman } & Control & 9.4 & 3.6 & 0.9 & 8.7 & 28.2 & 1.6 \\
\hline & Manipulator & 6.8 & 3.7 & 1.2 & 12.2 & 25.4 & 1.7 \\
\hline & Palisade & 4.8 & 3.8 & 1.7 & 13.6 & 39.8 & 3.2 \\
\hline & Manipulator + Palisade & 4.4 & 3.9 & 1.7 & 13.9 & 45.9 & 4.4 \\
\hline & $\operatorname{LSD}(\mathrm{P}=0.05)$ & 0.7 & 0.1 & 0.1 & 2.6 & 0.3 & 0.1 \\
\hline \multirow{5}{*}{ Fuzion } & Control & 14.0 & 3.4 & 0.6 & 6.0 & 19.6 & 1.2 \\
\hline & Manipulator & 7.7 & 3.5 & 0.7 & 7.9 & 21.1 & 1.2 \\
\hline & Palisade & 5.8 & 3.6 & 0.7 & 9.7 & 30.4 & 2.6 \\
\hline & Manipulator + Palisade & 5.2 & 3.7 & 0.9 & 9.2 & 33.8 & 2.6 \\
\hline & $\operatorname{LSD}(\mathrm{P}=0.05)$ & 2.4 & 0.1 & 0.1 & 0.8 & 7.6 & 0.1 \\
\hline \multirow{5}{*}{ FL62R1 } & Control & 13.9 & 3.4 & 0.5 & 7.7 & 13.1 & 1.3 \\
\hline & Manipulator & 8.6 & 3.5 & 0.7 & 7.7 & 15.9 & 1.4 \\
\hline & Palisade & 6.8 & 3.8 & 0.9 & 11.4 & 25.8 & 2.8 \\
\hline & Manipulator + Palisade & 5.7 & 4.3 & 0.9 & 10.7 & 34.0 & 2.8 \\
\hline & $\operatorname{LSD}(\mathrm{P}=0.05)$ & 1.4 & 0.4 & 0.1 & 0.5 & 3.5 & 0.1 \\
\hline \multirow{5}{*}{ AW725 } & Control & 11.9 & 3.2 & 0.6 & 7.5 & 18.7 & 1.6 \\
\hline & Manipulator & 5.9 & 3.4 & 0.7 & 9.6 & 22.7 & 1.9 \\
\hline & Palisade & 4.8 & 3.7 & 0.9 & 10.5 & 27.5 & 3.5 \\
\hline & Manipulator + Palisade & 4.5 & 3.9 & 0.9 & 15.5 & 32.5 & 3.5 \\
\hline & $\operatorname{LSD}(\mathrm{P}=0.05)$ & 0.5 & 0.1 & 0.3 & 4.2 & 5.4 & 0.1 \\
\hline
\end{tabular}

Note. CRLI: culm lodging resistance index; LSD (0.05): least significant difference at the 0.05 level.

\subsection{Chlorophyll Content}

It was obvious that PGRs increased chlorophyll content (Table 4); thus, they promoted photosynthesis to enhance the accumulation of biomass to strengthen the stem and increase grain yield. Compared with the control, the application of the combination resulted in the largest value between four treatments, across six cultivars, and the effect was greater with Palisade than with Manipulator. 
Table 4. Effect of PGRs on chlorophyll content at 10-day intervals

\begin{tabular}{|c|c|c|c|c|c|}
\hline Cultivar & Treatment & 41 days & 51 days & 61 days & 71 days \\
\hline \multirow{5}{*}{ AC Carberry } & Control & 47.5 & 49.2 & 46.4 & 42.8 \\
\hline & Manipulator & 48.2 & 49.9 & 47.2 & 50.4 \\
\hline & Palisade & 49.2 & 50.9 & 47.2 & 50.8 \\
\hline & Manipulator + Palisade & 49.8 & 51.3 & 50.5 & 53.8 \\
\hline & $\mathrm{LSD}(\mathrm{P}=0.05)$ & 1.8 & 0.8 & 0.8 & 0.9 \\
\hline \multirow{5}{*}{ AAC Scotia } & Control & 48.0 & 50.7 & 54.5 & 55.7 \\
\hline & Manipulator & 48.2 & 54.5 & 54.8 & 56.3 \\
\hline & Palisade & 53.6 & 56.5 & 57.7 & 59.9 \\
\hline & Manipulator + Palisade & 54.1 & 56.7 & 59.8 & 64.3 \\
\hline & $\operatorname{LSD}(\mathrm{P}=0.05)$ & 0.5 & 1.4 & 0.7 & 0.7 \\
\hline \multirow{5}{*}{ Hoffman } & Control & 47.5 & 54.3 & 54.3 & 54.8 \\
\hline & Manipulator & 49.2 & 55.3 & 55.1 & 56.5 \\
\hline & Palisade & 54.0 & 58.4 & 60.3 & 60.7 \\
\hline & Manipulator + Palisade & 55.2 & 59.4 & 61.9 & 61.5 \\
\hline & $\operatorname{LSD}(\mathrm{P}=0.05)$ & 0.9 & 1.1 & 0.9 & 0.6 \\
\hline \multirow{5}{*}{ Fuzion } & Control & 49.1 & 54.6 & 54.4 & 53.5 \\
\hline & Manipulator & 52.4 & 54.7 & 54.6 & 56.2 \\
\hline & Palisade & 53.9 & 57.0 & 59.4 & 59.9 \\
\hline & Manipulator + Palisade & 54.2 & 58.3 & 59.5 & 62.3 \\
\hline & $\operatorname{LSD}(\mathrm{P}=0.05)$ & 0.9 & 0.6 & 0.7 & 0.8 \\
\hline \multirow{5}{*}{ FL62R1 } & Control & 48.0 & 49.3 & 50.7 & 52.5 \\
\hline & Manipulator & 49.5 & 50.7 & 51.7 & 52.3 \\
\hline & Palisade & 52.6 & 57.4 & 59.1 & 61.4 \\
\hline & Manipulator + Palisade & 53.3 & 60.9 & 60.0 & 61.2 \\
\hline & $\operatorname{LSD}(\mathrm{P}=0.05)$ & 0.9 & 0.9 & 0.6 & 0.7 \\
\hline \multirow{5}{*}{ AW725 } & Control & 51.3 & 56.1 & 60.5 & 58.6 \\
\hline & Manipulator & 51.9 & 60.3 & 61.3 & 64.7 \\
\hline & Palisade & 56.7 & 62.9 & 63.7 & 65.0 \\
\hline & Manipulator + Palisade & 57.6 & 63.5 & 65.2 & 67.7 \\
\hline & $\operatorname{LSD}(\mathrm{P}=0.05)$ & 0.9 & 0.8 & 1.7 & 0.9 \\
\hline
\end{tabular}

Note. The relative chlorophyll content was recorded at 10-day intervals four times from 10 days after PGR spraying; LSD (0.05): least significant difference at the 0.05 level.

\section{Discussion}

Lodging causes a major loss in cereal yields and limits crop productivity, which is an important problem in crop production. Lodging is reported to be the primary cause of reduced grain yields in wheat (Stapper \& Fischer, 1990; Acreche \& Slafer, 2011). It is well established that there is a strong relationship between plant height and lodging. Wang et al. (2012) reported that plant height is a significant morphological feature in lodging. The greater the height, the more susceptible the plant is to lodging (Li et al., 2011). However, many studies have found that plant height is not the only trait related to lodging. Individual features cannot replace lodging assessment. Mukherjee et al. (1967) and Zuber et al. (1999) observed no association between height and lodging; shortening the height may even lead to reduced biomass production and hence may affect the yield (Stewart et al., 2003; Islam et al., 2007).

Dunn and Briggs (1989), and Wang and Hu (1991) reported that sclerenchyma were significantly associated with lodging resistance. In the studies of Stanca et al. (1979), there was no association between stem diameter or wall thickness of basal internodes. Over time, however, anatomical structural aspects, such as stem diameter, stem wall thickness, and CRLI, have also been observed to have important implications for the risk of lodging, as has the filling degree (Islam et al., 2007). Kelbert et al. (2004) reported that plant height and the length of basal internodes were the two main traits related to lodging, and some studies have found that the length, diameter, and 
wall thickness of basal internodes are significant traits to convey lodging resistance (Sameri et al., 2009; Yao et al., 2011). The CRLI acts as an important trait to evaluate lodging resistance (Dianliang et al., 2014). Beem et al. (1998) observed that the lowest two internodes were related to lodging resistance.

PGRs are chemical mixtures that suppress elongation or extension of crop internodes, thus reducing height and center of gravity height and improving other lodging traits to reduce the risk of lodging. Height reduction has been reported as an effect of PGRs by many researchers. Okuno et al. (2014) considered that gibberellin greatly reduced the height and center of gravity to increase lodging resistance. A similar trend was found with ethephon and chlormequat chloride (Espindula et al., 2009). The trinexapac-ethyl had longer persistence in inhibiting gibberellin biosynthesis to decrease dry matter production and internode length (Zagonel et al., 2002), and the Chlormequat reduced the amount of active gibberellin (Bode \& Wild, 1984). In the present study, the data clearly demonstrated that the crop height was significantly reduced, which was consistent with previous studies (Cailong et al., 2017). Palisade was more effective at reducing height than Manipulator, a finding that was in line with Espindula et al. (2009), and the combination of the two PGRs reduced the height substantially. The use of Manipulator and Palisade individually and in combination significantly improved lodging traits, increased the strength of second basal internode (Table 2, Figure 1), and, in the same way, enhanced lodging resistance at the anatomical level (Table 3, Figure 1). The application of the two PGRs in combination resulted in better lodging factors and yields than the individual PGRs and the control.

Biomass supports dry matter growth and yield formation (Berry et al., 2012). Some researchers have explained that biomass for lodging resistance was competed with that for yield determination (Berry et al., 2006; Piñera-Chavez et al., 2016). Chlormequat has been found to reduce the stem dry matter and affect the yield (Tinoco, 2005). In the experiments of Espindula et al. (2009) and Zagonel et al. (2002), chlormequat and trinexapac-ethyl did not affect the yield, while ethephon and chlormequat chloride alone and in a mixture were observed to increase the grain yield in field experiments (Shekoofa \& Emam, 2008; Merry et al., 2015). Paclobutrazol reduced the grain yield under non-lodging conditions (Dianliang et al., 2014). In consequence, whether or not spraying PGRs reduces the yield depends on the lodging conditions. No lodging occurred in this study, and the trait associated with lodging was strength (Table 2, Figure 1). The yield after PGR application was significantly reduced compared to the control (Table 1), possibly as a result of the redistribution of biomass during grain filling. The combination of PGRs produced a higher yield than the individual PGRs, a finding in agreement with the observations of Rolston (2014), although they were all lower than the yield of the control. The yield with Palisade was higher than the yield with Manipulator, which was contrary to Espindula et al. (2009). Lodging results in lower relative chlorophyll contents (Foulkes et al., 2011). Kerber et al. (1989) found that Trinexapac-ethyl does not affect the photosynthesis, however, in some experiments, the application of chlormequat and trinexapac-ethyl could increase photosynthesis rates and relative chlorophyll contents (Zagonel \& Fernandes, 2007), especially in drought conditions (Woźnica Z, 1981) The data of the present study indicated that the application of Manipulator and Palisade, both individually and in combination, may increase chlorophyll contents.

The literature has repeatedly shown that PGRs can reduce plant height and increase crop grain yield in the field. In this study, the application of Manipulator and Palisade individually and in combination decreased the wheat height and lodging, and reduced the grain yield in some degree, beyond that, they enhanced the stem strength and increased the wall thickness as well. Overall, the application of Palisade and Manipilator, individually or in combination to decrease crop lodging and protect yield potential under lodging-prone conditions would be a good strategy. Further investigation is needed to study the mechanism of combined PGRs response of lodging in wheat.

\section{Acknowledgements}

The authors acknowledge the support of the Agriculture and Agri-Food Canada research centre.

\section{References}

Acreche, M. M., \& Slafer, G. A. (2011). Lodging yield penalties as affected by breeding in Mediterranean wheats. Field Crop Research, 122, 40-48. https://doi.org/10.1016/j.fcr.2011.02.004

Baker, C. J., Berry, P. M., Spink, J. H., Sylvester-Bradley, R., Griffin, J. M., Scott, R. K., \& Clare, R. W. (1998). A method for the assessment of the risk of wheat lodging. Journal of Theoretical Biology, 194, 587-603. https://doi.org/10.1006/jtbi.1998.0778

Beem, J., Van Farquhar, T., Meyers, H., Reynolds, M. P., Singh, R. P., \& Van Ginkel, M. (1998). Influence of the Rht dwarfing genes on stem morphology, biochemistry and biomechanics and associated lodging effects in 
wheat. Proceedings of the 9th International Wheat Genetics Symposium, Supplement, Saskatoon, Canada: University of Saskatchewan. Germplasm Dev. Breed., 2(2), 366-368.

Berry, P. M., \& Spink, J. (2012). Predicting yield losses caused by lodging in wheat. Field Crops Research, 137, 19-26. https://doi.org/10.1016/j.fcr.2012.07.019

Berry, P. M., Sterling, M., \& Mooney, S. J. (2006). Development of a model of lodging for barley. Journal of Agronomy and Crop Science, 192, 151-158. https://doi.org/10.1111/j.1439-037X.2006.00194.x

Berry, P. M., Sterling, M., Spink, J. H., Baker, C. J., Sylvester-Bradley, R., Mooney, S. J., ... Ennos, A. R. (2004). Understanding and reducing lodging in cereals. Advances in Agronomy, 84, 217-271. https://doi.org/ 10.1016/S0065-2113(04)84005-7

Bode, J., \& Wild, A. (1984). Influence of 2-chloroethyl-trimethyl-ammonium chloride, (CCC) on Growth and Photosynthetic Metabolism of Young Wheat Plants (Triticum aestivum L.). J. Plant Physiol., 116, 435-446. https://doi.org/10.1016/S0176-1617(84)80135-2

Cailong, X., Yingbo, G., Beijing, T., Jianhong, R., Qingfeng, M., \& Pu, W. (2017). Effects of EDAH, a novel plant growth regulator, on mechanical strength, stalk vascular bundles and grain yield of summer maize at high densities. Field Crops Research, 200, 71-79. https://doi.org/10.1016/j.fcr.2016.10.011

Dianliang, P., Xiaoguang, C., Yanping, Y., Kunli, L., Weibing, Y., Yuhai, T., \& Zhenlin, W. (2014). Lodging resistance of winter wheat (Triticum aestivum L.): Lignin accumulation and its related enzymes activities due to the application of paclobutrazol or gibberellin acid. Field Crops Research, 157, 1-7. https://doi.org/10.1016/j.fcr.2013.11.015

Dunn, G. J., \& Briggs, K. G. (1989). Variation in culm anatomy among barley genotypes differing in lodging resistance. Canadian Journal of Botany, 67, 1838-1843. https://doi.org/10.1139/b89-232

Espindula, M. C., Rocha, V. S., Grossi, J. A. S., Souza, M. A., Souza, L. T., \& Favarato, L. F. (2009). Use of growth retardants in wheat. Planta Daninha, 27, 379-387.https://doi.org/10.1590/S0100-83582009000 200022

Feng, H. J., Zhang, S. P., Ma, C. J., Liu, P., Dong, S. T., Zhao, B., Zhang, J. W., \& Yang, J. S. (2014). Effect of plant density on microstructure of stalk vascular bundle of summer maize (Zea mays L.) and its characteristics of sap flow. Acta Agronomica Sinica, 40, 1435-1442. https://doi.org/10.3724/SP.J.1006. 2014.01435

Fischer, R. A., \& Stapper, M. (1987). Lodging effects on high-yielding crops of irrigated semi-dwarf wheat. Field Crops Research, 17, 245-258. https://doi.org/10.1016/0378-4290(87)90038-4

Foulkes, M. J., Slafer, G. A., Davies, W. J., Berry, P. M., Sylvester-Bradley, R., Martre, P., \& Reynolds, M. P. (2011). Raising yield potential of wheat. III. Optimizing partitioning to grain while maintaining lodging resistance. Journal of Experimental Botany, 62, 469-486. https://doi.org/10.1093/jxb/erq300

Guoping, Z., Jianxing, C., \& Bull, D. A. (2001). The effects of timing of N application and plant growth regulators on morphogenesis and yield formation in wheat. Plant Growth Regulation, 35, 239-245. https://doi.org/10.1023/A:1014411316780

Islam, M. S., Peng, S., Visperas, R. M., Ereful, N., Bhuiya, M. S. U., \& Julfiquar, A. W. (2007). Lodging-related morphological traits of hybrid rice in a tropical irrigated ecosystem. Field Crops Research, 101, 240-248. https://doi.org/10.1016/j.fcr.2006.12.002

Kelbert, A. J., Spaner, D., Briggs, K. G., \& King, J. R. (2004). The association of culm anatomy with lodging susceptibility in modern spring wheat genotypes. Euphytica, 136, 211-221. https://doi.org/10.1023/B:EUPH. 0000030668.62653.0d

Li, J., Zhang, H. C., Gong, J. L., Chang, Y., Dai, Q. G., Huo, Z. Y., \& Wei, H. Y. (2011). Effects of different planting methods on the culm lodging resistance of super rice. Scientia Agricultura Sinica, 44, 2234-2243.

Manipulator 620. (2015). Retrieved from https://www.google.ca/url? sa $=t \& r c t=j \& q=\& e s r c=s \&$ source=web\&cd= $1 \&$ cad=rja\&uact=8\&ved=0ahUKEwitosb8sc3VAhVM6YMKHXIDD14QFggrMAA\&url=https $\% 3 \mathrm{~A} \% 2 \mathrm{~F} \%$ 2Fwww.engageagro.com\%2FLabel\%2F59\%2FE\%2F1.pdf\&usg=AFQjCNGnlwMITRWY3g4ffri4sMCx-R $\mathrm{ZzVw}$

Merry, A. M., Dean, G., \& Botwright, A. T. (2015). What are the effects of chlormequat and trinexapac-ethyl alone or in combination on lodging, height and yield of winter wheat in Tasmania? Proceedings of the 17th Australian Society of Agronomy Conference (pp. 1-4). Hobart, Australia. 
Mukherjee, K. K., Kohli, S. P., \& Sethi, K. L. (1967). Lodging resistance in wheat. Indian Journal of Agronomy, $12,56-61$.

Neenan, M., \& Spencer-Smith, J. L. (1975). An analysis of the problem of lodging with particular reference to wheat and barley. Journal of Agricultural Science (Cambridge), 85, 494-507. https://doi.org/10.1017/ S0021859600062377

Okuno, A., Hirano, K., Asano, K., Takase, W., Masuda, R., Morinaka, Y., \& Matsuoka, M. (2014). New approach to increasing rice lodging resistance and biomass yield through the use of high gibberellin producing varieties. PLoS One, 9(2), e86870. https://doi.org/10.1371/journal.pone.0086870

Oleson, B. T. (1994). World wheat production, utilization and trade. In W. Bushuk \& V. F. Rasper (Eds.), Wheat: Production, Properties and Quality (pp. 1-11). Boston, MA, Springer US. https://doi.org/10.1007/ 978-1-4615-2672-8_1

Palisade EC Syngenta. (2015). Retrieved from http://www.syngenta-us.com/plant-growth-regulators/palisade-ec

Piñera-Chavez, F. J., Berry, P. M., Foulkes, M. J., Jesson, M. A., \& Reynolds, M. P. (2016). Avoiding lodging in irrigated spring wheat. I. Stem and root structural requirements. Field Crops Research, 196, 325-336. https://doi.org/10.1016/j.fcr.2016.06.009

Pinthus, M. J. (1973). Lodging in wheat, barley, and oats: the phenomenon its causes, and preventive measures. Advances in Agronomy, 25, 209-263. https://doi.org/10.1016/S0065-2113(08)60782-8

Pinthus, M. J., \& Rudich, J. (1967). Increase in grain yield of CCC treated wheat (Triticum aestivum L.) in the absence of lodging. Agrochimica, 11, 565-570.

Rademacher, W. (2000). Growth retardants: Effects on gibberellin biosynthesis and other metabolic pathways. Annu. Rev. Plant Physiol. Plant Mol. Biol., 51, 501-531. https://doi.org/10.1146/annurev.arplant.51.1.501

Rajala, A., \& Peltonen-Sainio, P. (2001). Plant growth regulator effects on spring cereal root and shoot growth. Agronomy Journal, 93, 936-943. https://doi.org /10.2134/agronj2001.934936x

Rolston, P., Chynoweth, R., Kelly, M., McCloy, B., \& Trethewey, J. (2014). Seed yield response of four cocksfoot (Dactylis glomerata L.) cultivars following the application of stem shortening plant growth regulators. New Zealand Journal of Agricultural Research, 57, 332-341. https://dx.doi.org/10.1080/ 00288233.2014 .925942

Sameri, M., Nakamura, S., Nair, S. K., Takeda, K., \& Komatsuda, T. (2009). A quantitative trait locus for reduced culm internode length in barley segregates as a Mendelian gene. Theoretical and Applied Genetics, 118, 643-652. https://doi.org /10.1007/s00122-008-0926-9

Shekoofa, A., \& Emam, Y. (2008). Effects of nitrogen fertilization and plant growth regulators (PGRs) on yield of wheat (Triticum aestivum L.) cv. Shiraz. Journal of Agricultural Science and Technology, 10, 101-108.

Srivastava, L. M. (2002). Plant growth and development: Hormones and environment (p. 772). San Diego: Academic Press. https://doi.org/10.1016/B978-0-12-660570-9.50179-9

Stanca, A. M., Jenkins, G., \& Hanson, P. R. (1979). Varietal responses in spring barley to natural and artificial lodging and to a growth regulator. Journal of Agricultural Science (Cambridge), 93, 440-456. https://doi.org/10.1017/S0021859600038144

Stapper, M., \& Fischer, R. A. (1990). Genotype, sowing date and plant spacing influence on high-yielding irrigated wheat in southern New South Wales. II. Growth, yield and nitrogen. Australian Journal of Agricultural Research, 41, 1021-1041. https://doi.org/10.1071/AR9901021

Stewart, D. W., Costa, C., Dwyer, L. M., Smith, D. L., Hamilton, R. I., \& Ma, B. L. (2003). Canopy structure, light interception, and photosynthesis in maize. Agronomy Journal, 95, 1465-1474. https://doi.org/10.2134/ agronj2003.1465

Tolbert, N. E. (1960). (2-Chloroethyl) Trimethyl ammonium chloride and related compounds as plant growth substances. II. Effect on growth of wheat. Plant Physiology, 35, 380-385. https://doi.org/10.1104/ pp.35.3.380

Tripathi, S. C., Sayre, K. D., Kaul, J. N., \& Narang, R. S. (2003). Growth and morphology of spring wheat (Triticum aestivum L.) culms and their association with lodging: effects of genotypes $\mathrm{N}$ levels and ethephon. Field Crops Research, 84, 271-290. https://doi.org/10.1016/S0378-4290(03)00095-9 
Wang, C. Y., Dai, X. L., Shi, Y. H., Wang, Z. L., Chen, X. G., \& He, M. R. (2012). Effects of nitrogen application rate and plant density on lodging resistance in winter wheat. Acta Agronomica Sinica, 38, 121-128. https://doi.org/10.3724/SP.J.1006.2012.00121

Wang, Q. Y., \& Hu, C. H. (1991). Studies on the anatomical structures of the stalks of maize with different resistance to lodging. Acta Agronomica Sinica, 17, 70-75.

Wiersma, D. W., Oplinger, E. S., \& Guy, S. O. (1986). Environment and cultivar effects on winter wheat response to ethephon plant growth regulator. Agronomy Journal, 78, 761-764. https://doi.org/10.2134/ agronj1986.00021962007800050002x

Wiersma, J. J., Dai, J., \& Durgan, B. R. (2011). Optimum timing and rate of trinexapac-ethyl to reduce lodging in spring wheat. Agronomy Journal, 103, 864-870. https://doi.org/10.2134/agronj2010.0398

Woźnica, Z. (1981). Wpływ Camposanu (etefon) na niektóre cechy morfologiczne, wyleganie i plon żyta ozimego. Rocz. AR Pozn., Rozpr. Nauk., 114, 14-28.

Yao, J. B., Ma, H. X., Zhang, P. P., Ren, L. J., Yang, X. M., Yao, G. C., ... Zhou, M. P. (2011). Inheritance of stem strength and its correlations with culm morphological traits in wheat. Canadian Journal of Plant Science, 91, 1065-1070. https://doi.org/10.1139/CJPS2011-033

Zagonel, J., \& Fernandes, E. C. (2007). Rates and application times of growth reducer affecting wheat cultivars at two nitrogen rates. Planta Daninha, 25, 331-339. https://doi.org/10.1590/S0100-83582007000200013

Zagonel, J., Venancio, W. S., \& Kunz, R. P. (2002). Effect of growth regulator on wheat crop under different nitrogen rates and plant densities. Planta Daninha, 20, 471-476. https://doi.org/10.1590/S0100-835820020 00300019

Zuber, U., Winzeler, H., Messmer, M. M., Keller, M., Keller, B., Schmid, J. E., \& Stamp, P. (1999). Morphological traits associated with lodging resistance of spring wheat (Triticum aestivum L.). Journal of Agronomy and Crop Science, 182, 17-24. https://doi.org/10.1046/j.1439-037x.1999.00251.x

\section{Copyrights}

Copyright for this article is retained by the author(s), with first publication rights granted to the journal.

This is an open-access article distributed under the terms and conditions of the Creative Commons Attribution license (http://creativecommons.org/licenses/by/4.0/). 